Secondly, it is unfortunate that naturalists were not likewise sent to Oahu, in the Sandwich Islands, where there was likewise an astronomical station in 1874 . The Sandwich Islands, as was pointed out by our correspondent in 1870, are the seat of a most peculiar indigenous flora and fauna, which is now fast perishing beneath the assaults of European weeds and animals introduced from other countries. Dr. Finsch, who was lately at Honolulu on his way to the Northern Pacific, tells us (Ibis, 1880, p. 79) that during a week's stay in that city and its vicinity, he saw no birds except introduced species, and had to go far into the interior to obtain examples of the indigenous Avi-fauna, and that the "native forests are going in the same way." It is a great misfortune, then, that this should happen before we have any good account of this peculiar flora and fauna which rivals in eccentricity even that of the Galepagos. And as another Transit occurs in 1882, we trust that should our astronomers again visit any one of the Sandwich Islands group, a staff of efficient naturalists will be sent in their company.

\section{ARTIFICIAL DIAMONDS}

T NDER the heading of "The Crystallisation of Carbon" Mr. Crookes writes as follows in the last number of the Chemical News:-

Since sending the telegram ${ }^{x}$ announcing that carbon crystals, apparently diamond, could without difficulty be produced from any carbon compound, Mr. Mactear bas sent me several specimens of his supposed artificial diamond. He has also called upon me with other specimens, and has explained the whole process by which he obtains such remarkable results. As, however, he has sent to the Royal Society a paper which will probably be read in the course of a week or two, I am not yet at liberty to give details of the process.

The general character of the specimens now in my possession may be described as irregularly shaped masses from $\mathrm{I} \mathrm{mm}$. downwards in diameter, with rounded angles, and showing no definite crystalline appearance. They are whitish looking, translucent, and as a rule lustreless; many pieces are almost spherical and appear like fragments of corundum which have been water worn. Amongst these are perfectly clear fragments larger in size, some being 3 or $4 \mathrm{~mm}$. across, having a conchoidal fracture exactly like glass.

In a paper "On Molecular Physics in High Vacua," read before the Royal Society in March last, and now being published in the Philosophical Transactions, I referred to the remarkable power possessed by the molecular rays in a high vacuum of causing phosphorescence in bodies on which they fall, and I remarked that the only body which surpassed Becquerel's luminous sulphides both in brilliancy and variety of colour is the diamond. Most of these gems, whether cut or in the rough, when coming from the South African fields, phosphoresce of a brilliant light blue colour. Diamonds from Brazil shine with different colours, such as bright blue, pale blue, apricot, red, yellowish green, orange, and light green. A beautiful collection of diamond crystals, kindly lent me by Prof. Maskelyne, phosphoresced with nearly all the colours of the rainbow, the different faces glowing with different shades of colour. On receiving the specimens from Mr. Mactear, I immediately submitted them to the molecular discharge. The following are the results I have at present obtained :-

In a high vacuum the specimens phosphoresce brightly of different colours-pale blue, orange, apricot, and yellowish green. The clear glassy fragments are also phosphorescent. The appearance of the phosphorescence is very similar to that shown by small, rough diamonds from Brazil, called in the trade "Boart;" indeed, had I not known the history of the fragments in my tube, I ${ }^{x}$ Chemical Nezus, vol. xl. p. 306 (December 26, 1879). should, from their appearance, have said that they were small fragments of Brazilian Boart.

The opaque rounded appearance of the fragments is unlike that of the natural diamond, but by heating a rough diamond before the blowpipe until it has partly burnt away, it assumes a very similar appearance to that of Mr. Mactear's crystals, and it is therefore not unlikely, from their mode of preparation, that these crystals have undergone partial combustion after their formation-a fact which would explain this difference in appearance. Other specimens having been placed by Mr. Mactear in competent hands, with a view of determining their hardness and chemical properties, I have refrained from making experiments in this direction.

W. C.

We append a letter on the subject from Prof. Maskelyne in the Times of the 8th inst. :-

As I know that a portion of the public is very much interested in the diamond question, and in the result of the interview Mr. Mactear announced that he and I. were to have in connection with it, I think, perhaps, it will be well to say that I have had the pleasure of working with that gentleman many hours yesterday and to-day, and that our results so far convince me that, while my own conclusions, as announced in the Times, are borne out as regards at least the portion of the substances on which I worked, there are other portions of those substances that differ from these in properties and still require investigation; that, in fact, the material is a mixture of different bodies. When I say that I have as yet no evidence of the existence of crystalline carbon, whether as diamonds or in some other condition, among these bodies, I feel that Mr. Mactear makes a reasonable request of me in asking that I should invite a suspension of opinion regarding a discovery he believes that he has made. A portion of the material he has produced is very hard, and, I believe, bears out his claim to have scratched topaz and sapphire. Mr. Mactear wishes me to add that the diamond has been also abraded by his product and to inclose to you a certificate to that effect. Mr. Mactear wishes me also to state that he claims simply to have produced a crystalline form of carbon irrespective of the question of whether this is the diamond.

I am, Sir, your obedient servant,

Nevil S'TORY-MASKELYNE

British Museum, January 7

We may state that in the Times of the same date is a certificate from Mr. L. Boston, of Glasgow, that he has been able "to scratch a diamond and to engrave two rubies, two sapphires, an amethyst, and a cairngorm" with Mr. Mactear's "crystallised carbon sand."

\section{THE "TIMES" ON BRITISH BIRDS}

NATURALISTS live a life of surprises, but the surprise with which ornithologists must have one day last week received certain positive assurances of the leading journal would surely overstep the bounds of ordinary astonishment. We have, no doubt, been passing through a "silly season" of unwonted severity, as the morris-dance of late performed by many of the pseudoornithological correspondents of the Times proves; but a recent leading article in that journal eclipses all else that it has published on the subject.

After declaring that "our birds are the glory of the land," and piously ascribing that glory to the upper regions, the writer goes on to compare England with France in the matter of its birds, saying, of course, nothing that was not quite well known before, except the extraordinary statement that "France has produced ornithologists, but they have had to leave her shores." The meaning of this is entirely beyond us, for every one knows who cares to know that France now possesses a large number of ornithologists-and one indeed, $M$. 
Alphonse Milne-Edwards, who on some points is the greatest ornithological authority that has ever lived. We are then told of an Oxford undergraduate who "took a walk with his gun in Bagley Wood and brought home fifty different specimens which he carefully stuffed." "He had a museum," it is added, "of several hundreds." We are not told whether this Oxford undergraduate's conduct is worthy of praise or blame, nor would it much signify, for the writer is evidently confused in his notion of "specimens" and "species." To kill specimens of fifty different species in one day and in one wood, though not easy, could no doubt be done in many places, but it would be hard to kill fifty birds that were not different specimens! Would the writer also be surprised to learn that " a museum," or a collection, as people nowadays more humbly style it, "of several hundreds," was some fifty years ago by no means uncommon, and that of late years private collections include not only thousands of specimens, but thousands of species?

But now comes the most astonishing assertion of all. We are told that "Mr. Morris describes more than twelve hundred birds," and that there may be no mistake in the writer's meaning, he subsequently repeats the statement in this wise: "Of the twelve hundred British birds, a good many are represented by a single stray specimen," and so on! The ornithologists of this country have hitherto been deemed by their continental brethren somewhat too hasty in enrolling as "British" every chance waif from foreign lands and seas that has had the ill luck to show itself (and of course be shot) within the limits of the United Kingdom, and we have never understood that on the most liberal interpretation of the expression, "British birds," the number has exceeded four hundred. How blind and inefficient have they been when they have omitted more than two-thirds of the species that occur here! It is really to be hoped that the writer of the leading article on English birds in last Thursday's Times will bring them to a due sense of their neglected duties by furnishing a list of the 800 species whose rights of citizenship have been so shamefully ignored, and if he will at the same time say in which edition of Mr. Morris's work "more than twelve hundred" British birds are described, he will possibly contribute to a more comfortable understanding of the matter, for $\mathrm{Mr}$. Morris has hitherto been supposed to follow very closely the late Mr. Yarrell in the information he gives, so that when the latter in his last edition included 354 species, the former a few years later made the number 358 !

There are many other assertions in the same article which excite a degree of amazement inferior only to the last particularised, and we have heard persons suggest that the writer must have been all the while perpetrating a solemn joke.

\section{EDISON'S ELECTRIC LIGHT}

THE Times New York correspondent gives some interesting details in Monday's paper of Mr. Edison's new form of electric lighting and the steps by which he was led to its discovery. So far the light has withstood every test that has been tried, and so confident do the public seem that success has been attained at last, that the shares of the Edison Company have risen from 20 dollars to 3,500 dollars.

The Philadelphia correspondent of the same journal gives some further information in yesterday's issue. Probably 200 people make up the population of Menlo Park, we are told, nearly all Edison's workmen and their families. He gets an income of 40,000 dollars to 50,000 dollars a year from his various inventions, and he spends it all, the most of it for machinery and wages, and the balance in charity. The correspondent then gives some interesting details concerning $\mathrm{Mr}$. Edison, his habits, his enthusiasm, and his relations with his numerous employés. There is no discipline enforced or any apparent time-table for work, yet with all hands it seems a labour of love, and if you pick out from the crowd the grimiest and most woe-begone of the whole party of overworked alchemists it will be Edison himself. It appears to have been the system at Menlo Park, as with the alchemists of old, to do most of the work at night, and it seems the regular habit of Edison and his chief subordinates to work straight through the twenty-four hours without stopping, until tired nature compels them to drop down in any handy place and go to sleep. "We went there," the correspondent writes, "hoping that Edison had succeeded, but nevertheless sceptics, and we came away thorough believers. His lamps were burning when we arrived, and they burnt continuously until our departure, excepting from half-past four to half-past five P.M., when about an hour's time was taken in putting in a new generator to do the work, which be had just finished and desired to try. During the daylight we could see the lamps burning, supplied by the first generator, and perceived that the little carbon loop or horseshoe giving the light remained intact. After dark, when the second generator went to work, we saw for three hours the lamps successfully burning as a complete substitute for gas for every purpose for which illumination was necessary at Menlo Park. The gas jets were idle, being put out of use by the steadier and more genial glow of the electric light. We ate our supper by it in the little restaurant that has been established at the Park, and I sat down in Edison's office under two of his lamps attached to a gas bracket and wrote the rough draft of the telegram sent to the Times. In this room a telegraph operator worked in a corner with an Edison lamp in a movable table stand illuminating his work. Down stairs his bookkeeper was paying off the hands by the aid of two more electric lights on a gas bracket. Out in the roadway in front of the building two street lamps were set up with the Edison light in full operation. In his workshop the engineer was running his engine and a couple of men watching the operation of the new generator by the light of more Edison's lamps, while in the laboratory some fifteen of them were giving light for various operations, and downstairs a young man sat at the regulator, and, watching another light, by the aid of the galvanometer, kept the flame steady, just as the regulator is worked constantly in the gas-house to adjust the gas pressure, so that it will compensate for turning lights on or off throughout the town. It was between seven and eight o'clock on a dark winter evening, and the electric light had put into disuse both the gas jets and the petroleum lamps that were in profusion around. I visited four dwellings in the village and saw the Edison lamps doing the work of illumination for all household purposes in each of them. In Edison's own house, where he had at least a dozen of them, we remained over half an hour, and I shall never forget the glee with which Edison listened to the reading of a newspaper slip, wherein an ambitious ' expert' offered to forfeit roo dollars for every lamp that Edison could keep burning over twenty minutes."

\section{NOTES}

ON Friday, the 9th inst., the St. Andrew's University Court agreed to report to the Queen in Council in favour of an application by Prof. Swan to be permitted to retire, on the ustal retiring allowance, from his Chair of Natural and Experimental Philosophy in the University, on the ground of failing health.

Mr, E. W. Cooke, R.A., F.R.S., whose death at the age of sixty-nine years, took place at Groombridge on the $4^{\text {th }}$ inst., deserves some notice in these pages for his connection in various ways with science. From his boyhood he had the keenest interest in natural history, and was probably one of the first amateur horticulturists. He was connected with most of our scientific societies, and was an early member and constant 